\title{
A THEOLOGICAL REFLECTION ON THE STORIES OF POLICE OFFICERS WORKING UNDER A NEW CONSTITUTION
}

\author{
Authors: \\ Brian Burger ${ }^{1}$ \\ Julian Müller ${ }^{2}$

\section{Affiliations: \\ ${ }^{1}$ Lyttelton Methodist \\ Church, Pretoria, South \\ Africa} \\ ${ }^{2}$ Department of Practical \\ Theology, University of \\ Pretoria, South Africa

\section{Correspondence to: Brian Burger \\ e-mail: \\ brian@lytteltonmethodist. org.za}

\section{Postal address:} PO Box 14209, Lyttelton, 0140, South Africa

\section{Keywords:}

police officers; constitution; crime fighting; practical theology; theology and the community

\section{Dates:}

Received: 29 Oct. 2008

Accepted: 30 June 2009 Published: 28 Sept. 2009

How to cite this article: Burger, B. \& Müller, J., 2009, 'A theological reflection on the stories of police officers working under a new constitution', HTS Teologiese Studies/ Theological Studies 65(1), Art. \#311, 5 pages. DOI: 10.4102/hts.v65i1.311

\section{This article is available} at:

http://www.hts.org.za

(C) 2009. The Authors. Licensee: OpenJournals Publishing. This work is licensed under the Creative Commons Attribution License.

\section{ABSTRACT}

Fighting crime in the new South Africa has taken on new challenges under a new constitution. Using a narrative approach to research, the stories of police officers were listened to and reflected upon theologically. This process was carried out within a postfoundationalist and social constructionist paradigm that enabled further dialogue with other disciplines, seeking common ground as well as points of difference.

\section{INTRODUCTION}

The political landscape in South Africa has changed and new policing challenges have emerged. A new constitution has necessitated a change in policing practices from the para-military model implemented in 1829 by Sir Robert Peel in the London Metropolitan Police and adopted in South Africa, towards a more community- based policing structure (Van Rooyen 1995). The constitution requires that the police service needs to be made more accountable for its actions to the community.

As a practical theologian and pastor, my interest in community policing has grown since the mid-1990s, spurred on by Gordon MacDonald's own 'renewed challenge of insisting that my life of following Christ be absolutely nose to nose with what is going on in the "streets" where people live and work' (MacDonald 1989:10). This led to my curiosity into how members of the South African Police Service (SAPS) were adapting to these changes and emerging challenges. This article emerges from a PhD research project that I conducted with police officers in the middle-management structure of the SAPS.

A narrative approach within a postfoundationalist and social constructionist paradigm was adopted for the purposes of this research. This article will give a brief explanation of the implications of this method for the research. It will then list four of the issues raised by police officers, drawing them into dialogue with the insights of others. Four corresponding theological reflections associated with these issues will be provided with a view to identifying the areas of God's activity within the workplace of these members of the police service. Lastly, it will identify a number of the challenges facing the church in its ministry to the SAPS under our new constitution.

\section{A POSTFOUNDATIONALIST AND SOCIAL CONSTRUCTIONIST WORLDVIEW}

This research was conducted within a postfoundationalist paradigm, which is consistent with social constructionism. This section will explain what is meant by these terms because they provide the philosophical basis to the research methodology employed.

Postfoundationalism has emerged from the work of Wentzel van Huyssteen who sought 'to move beyond the epistemological dichotomy of foundationalist objectivism and nonfoundationalist relativism' (Van Huyssteen 1999:8). In other words, it positions itself as an alternative to the modernist (foundationalist) claim to universal truths and to postmodern (nonfoundationalist) relativism. It seeks to utilise the strengths of both in order to facilitate meaningful dialogue between different disciplines, without having any discipline claiming superior knowledge. This approach facilitates conversations between, for example, theology and criminology, seeking points of common ground while also allowing for disagreement so as to gain a deeper understanding of the issues. Therefore, the insights gained through this research do not necessarily apply to all police personnel at all points in time, but form part of an ongoing dialogue about the issues pertinent to members of the police.

Social constructionism recognises that our knowledge emerges in an interrelationship between people, their culture, beliefs, institutions and so on, as they interact with each other. Each of these forms part of how we interpret our world. Language also forms an integral part of social constructionism because 'The language we grow up and live in within a specific culture, specifies or constitutes the experiences we have' (Kotzé \& Kotzé 1997:32). Thus, finding new ways of speaking about our reality can open the way towards preferred ways of living.

Julian Müller argues in favour of a connection between social constructionism and postfoundationalism saying that both have a 'deep-rooted belief that we, with our rationality, are socially constructed' (Müller 2004:299). In their article, Karlijn Demasure and Müller identify the common criterium as a preference for stories that are socially constructed instead of concepts. These stories are locally situated, and yet are also in dialogue with traditions and engage in interdisciplinary insights (Demasure \& Müller 2006:419). This postfoundationalist and social constructionist epistemology forms the basis of the narrative approach taken in this research.

\section{THE NARRATIVE APPROACH TO RESEARCH}

The narrative approach listens to various stories including those of the individuals, who are referred to as 'co-researchers' (Müller, Van Deventer \& Human 2001:77), and 'centres people as the experts in their own lives' (Morgan 2000:2). In a narrative approach, the researcher does not take an external, objective 
position, but 'strives for participatory interaction' (Müller, Van Deventer \& Human 2001:78). Because of this, I refer to the police officers as my co-researchers or research participants. Together we explored their experiences and sought to interpret them, which is why this article uses the pronoun 'we' on a regular basis. However, these police officers remained the 'experts' of their own lives and had the final word in terms of any interpretations that were made regarding their local situation.

Stories within the society and culture were also taken into account. To do this, the historical context of South Africa was taken into account, and we listened to media stories on policing, as well as stories discovered by other researchers. Using the contribution of liberation theology and feminism to practical theology, we deconstructed those stories to see whether they were still appropriate within a new emerging context. Thus, the co-researchers did not only provide data but were involved in the interpretation and deconstruction process as far as possible. Our hope was that we would discover some 'unique outcomes' (White \& Epston 1990:56) or 'sparkling moments' (Freedman \& Combs 1996:89) that may be described as new insights or events that defy the problem-orientated discussions and make for preferable living.

\section{LISTENING TO THE STORIES OF POLICEMEN}

The narrative approach taken in this research wanted to pay respectful attention to the stories of police members within the broader context of adapting to a new South Africa. This article is a summarised section of a doctoral thesis completed on this topic (Burger 2008). Living in the Kwazulu-Natal Midlands, where this research took place, allowed me to build long-term relationships with members of the police service. I was involved in the Community Police Forum, cooperated in many of their projects and visited stations on a weekly basis for prayer and scripture reading. The three police officers who were willing to participate in this research were appointed in management positions at local police stations in the area. They became part of the entire research project, from determining the topic to the final conclusions that were made. One of the reasons I recruited these specific policemen was because they each had a wealth of police station management experience in the old apartheid South Africa (pre-1994) and in the new, democratic South Africa (post-1994). Drawing comparisons between these two eras could be helpful in identifying some of the challenges of working under a new constitution. The reason I chose to focus on only a few participants was to explore their stories thoroughly and qualitatively. Themes emerged from the stories and not merely from the assumptions I had in formulating a predetermined questionnaire. These themes were checked with all the participants and each one was given the opportunity to comment on the ideas that were derived from the opinions of the other participants. As the facilitator of this research, I was surprised at how similar the themes actually were, even though they were rooted in different stories. From there a theological reflection of these themes took shape, taking a look at what informed our opinions and how theology could challenge us. The issues raised by these police officers may resonate with others in the country because the research of others was taken into account. However we also recognised that experiences can differ from place to place and that our conclusions were local. This is consistent with our social constructionist and postfoundationalist position as explained above. Pseudonyms have been used for the purposes of this article, namely Noel, Dieter and Roddy.

Four of the themes we identified included: a decreasing standard of work; leadership and other internal relationships; the effects of human rights; and the implications of working with a wider community.

\section{Standard of work}

The first theme that emerged from all the co-researchers was that of the drop in the standard of police work. This was evident in general laziness, corruption and inadequate training. As a result, much of the public's negative perceptions of police can be justified.

Referring to the 'old days', one detective, Noel, said that they used to be proud to display recovered stolen goods, to smash syndicates and to reward their informers (now known as 'sources'). He insisted that the majority of the people he works with today do not care about their work and are only concerned about receiving their salary at the end of the month. The lack of follow-up interviews with complainants, poor docket preparation for court and laziness were cited as examples. In his frustration he went so far as to say that 'Batho Pele' (meaning 'People First' - an initiative to encourage good service in all government departments) was non-existent and referred to uncaring detectives as 'defectives.' Later in the conversation he conceded that there were exceptions where satisfying successes had been accomplished through good policing. We also agreed that inappropriate bail was granted to criminals who continue with crime, which leads to discouragement amongst the police who have to track and re-arrest these people. It was felt that this takes time that could be spent solving other cases.

The assumption may be made that further training could contribute to providing a solution in this regard. While some police members use courses to improve their skills, there are those who attend but do not implement the knowledge acquired. For example, computer literacy is provided to those in affirmative action posts in order to improve communication, but they still do not respond to their e-mails. A month-long street survival course to sharpen the crime fighting and fitness levels of police officials was watered down to a two-day course. And so, further training, as vital as it is, seemed not to be a guarantee of improved performance amongst police officers.

Corruption has been another well-documented aspect of the low standard of work. All participants admitted that corruption has always been present in the police service, from bribery to police officers actively taking part in criminal activities. It came as no surprise that personnel from the highest to the lowest ranks have been caught and charged. Co-researchers spoke of a slippery slide deeper into corruption that a police officer should never have become involved in from the start.

As a result of the above, public perceptions on policing evoke a mixed response. Some members of the public have experienced professional and effective work performed by members of the police service, while others remain waiting for statements to be taken years after their incident. Internal relationships between members of the police are also affected by different standards of work - between those who work diligently and those who do not, and between members at different levels of the chain of command.

\section{Leadership, promotions and internal relationships}

Since 1994, the SAPS has had to integrate affirmative action policies in its promotion considerations. This process has included top management personnel with security branch experience being replaced by others, but conducted in such a way that the entire force is not alienated. For example, General Johann van der Merwe was eased out and was replaced by George Fivaz (Steinberg 2001:9). Fivaz was replaced by Jacob Sello (Jackie) Selebi who had no previous policing experience and who was eventually suspended. At local station level, racial considerations, declining levels of trust and respect, and a lack of promotion incentives have furthermore characterised relationships.

One of the branch commanders, Dieter, expressed frustration with his station commander who seemed to have a racial vendetta against all white and Indian members of the police. Lists of grievances and counter-charges led to a tense stalemate 
situation, hindering the efficient functioning of the station. He speculated that top management structures did not offer any assistance because they had their own careers to protect by being politically correct. Dieter was eventually transferred to another station. Top management saw this as a solution, but it does not resolve the issue of the poor relationship existing between them.

By contrast, Noel's white station commander was disliked because he did his work very well, causing a considerable drop in crime in a black residential area. The 'defective detectives' organised a community march to oust him, but had to rely on a 'rent-a-crowd' of primary school children because the community supported the station commander. Noel commented that he wished his 'defectives' would put the same level of effort into their work as they did for the march! This station commander was one who did his work well and took care of the police members under his supervision. Even Dieter, who was at another station, sought his advice in dealing with his commander.

Evident from the above, it seems that relationships between members of the police service are not always cordial. The assumption that was once made of the police being a closed organisation consisting of members who cover up for one another has been shown to be oversimplified. Yes, there are times when immediate dangers of life-threatening situations require a dependence on each other to provide support. However, this does not mean that members of the service trust or even like each other in the normal events of life.

Promotions also constitute a contentious issue amongst police officers working under a new constitution. These promotions do not always seem to be dependent on competency, experience or training. Some promotions, such as that of Dieter's station commander, were authorised even before the person had completed the required course. Initially it seemed as though only the positions of white police officers had been frozen due to affirmative action. However, the South African Human Rights Commission was called upon to investigate an e-mail sent from National Assistant Commissioner NNH Mazibuko in which it was stated that no Indian policemen were to receive promotions in Kwazulu-Natal (Sunday Tribune Herald 2006: p. 1). Furthermore, in his research, Anthony Altbeker relayed a story of a black policeman who, although he had many years of experience, was never considered for promotion (Altbeker 2005:209). All the participants agreed that promotions should be based on performance, or else the process may lead to a lack of respect for members of the higher ranks who may have been promoted for reasons that are less acceptable.

One unique outcome that emerged during this research was the unexpected promotion of one participant. Roddy, who had previously said that hard work did not seem to count for anything when it came to promotions, was indeed promoted. It would thus seem that hard work had paid off for him and that it had been recognised by his superiors.

\section{Human rights}

The news media regularly runs stories of the abuse of power by some members of the SAPS, whether it be through the physical ill-treatment of suspects or through hasty arrests that later prove incorrect. Amnesty International has also documented shocking behaviour and discriminatory attitudes by the police (Amnesty International 2002:21). Lisa Vetten, who was at the Centre of the Study of Violence and Reconciliation, has also spoken regularly on television about the regular lack of care and concern shown by the police towards victims of rape and domestic violence.

Regarding the torturing of suspects, one participant told of his experience when he was a young policeman in the 'old' South Africa. While attempting to extract information from an apprehended suspect by beating him, another police officer came into the room and charged him. As a policeman he was sentenced to community service and placed under house-arrest. This participant shared that, while he initially felt betrayed by the other policeman (again revealing the incorrect assumption that police officers cover up for each other), it has helped him to become a better policeman today. Although it is common knowledge that torture still takes place, this policeman no longer resorts to such methods in his investigations.

Laws such as Section 49 of the Criminal Procedure Act 51 of 1977, which have to do with the use of force (including lethal force) when carrying out an arrest, have been amended under the new constitution. This, in turn, has evoked sharp reaction. The amendment, proposed in 1998 on the use of firearms and lethal force, allowed for self-defence, or if a third party was under threat, or if there was risk of future harm being done (the third portion being declared unconstitutional by the Constitutional Court, case CCT 28/01 between the State versus Edward Joseph Walters and Marvin Edward Walters). Many officers felt that their power had been eroded and that they would be targets for criminals using this law to their advantage, shooting first before police could return fire. It goes without saying that the initial confusion needed to be overcome. However, Selebi wrote in a letter to all police stations (dated 24 May 2002) that: 'The right and indeed the duty - of police officers to protect their lives and personal safety and those of others is clearly endorsed and in no way diminished.' The co-researchers in this project felt that this law had not substantially changed the way they themselves carry out their police work. They stated that each police member must just be clear about what the law entails.

In debating the subject of human rights, police officers have always posed the question about whose rights are involved - the rights of the suspect or that of the victim. During this research it was stated that the victim did not 'ask' to be raped, but the criminal 'chose' to violate another person's rights. Furthermore, in some cases criminals seem only to be concerned when their own rights are violated, and not about the fact that others have rights too. It was agreed that there is a lot of carelessness on the part of the police when it comes to abusing their power, such as wrongful arrests and excessive force. However, it must be borne in mind that police members have seen victims horrifically violated and are not unaffected by what they are exposed to. Thus, when police officers catch a suspect who is not cooperative to the police's invitation into custody, the natural inclination is to mete out immediate justice. However, as tempting as this option may be, it was agreed that the anger felt towards a criminal must be redirected constructively and intelligently to ensure a successful prosecution.

Chris van der Merwe and Pumla Gobodo-Madikizela, writing about a narrative approach to healing victims of trauma, state: 'When we reflect on the notion of justice, particularly in relation to human rights abuses, we need to think of justice not as an end in itself, but as a process. In that process we should strive towards a critical balance between justice and compassion' (Van der Merwe \& Gobodo-Madikizela 2008:50). Striking this balance, as difficult as it may be, will prevent the extremes of harsh judgmentalism (justice without compassion) and a soft sentimentalism (compassion without justice). As such, we, as co-researchers, needed to recognise that establishing a culture of human rights is important, but is not a realistic possibility in the near future.

\section{Working with the community and other agencies}

The research participants concurred that members of the community have always been involved (as informers or sources) in the fight against crime, and that the police cannot do anything without them. There is now (in the post-1994 era) the explicit acknowledgement that we all need each other if we are to succeed. One of the ways this is happening is through community police forums, set up to monitor police activities and assist in crime prevention strategies.

Community police forums constitute one of the primary ways in which the new model of community policing has been realised. 
Different levels of success have been accomplished, varying from station to station. These forums have been established in terms of Section 12 of the Constitution of the Republic of South Africa (Act 108 of 1996) and the South African Police Service Act No. 68 of 1995. In the experience of the research participants, these forums worked well. Regular feedback on crime trends, community awareness programmes, neighbourhood watches, victim support, prayers at the local station and joint workshops on domestic violence and drugs at schools, farms and factories all formed part of the activities.

One of the negative aspects of community participation is vigilantism. This occurs when members of the public no longer have faith in the police and the legal system's ability to deal with crime in their area. People then resort to their own forms of meting out justice. In the apartheid era, informers were tracked down and punished whether they were guilty or not. Corporal punishment and even death by burning ('necklacing') were among the methods used. These past practices, though no longer politically motivated, are still used today. In some cases the police have rescued the suspect, while at other times they have been forced to stand by helplessly. Noel found himself in the latter situation a week before my interview with him.

A further aspect in terms of working with a wider community has emerged through the role of trade unions. For many in the SAPS, trade unions used to be regarded very negatively. However, throughout the year of this research, Roddy included representatives from these unions at every station and community meeting. They were included in all decisions made and a note was made when they did not attend. In this way, he said, they could never come back to him and dispute a decision made at his station. This creativity and diligence was possibly the reason why he was the only white male policeman to receive a promotion in Kwazulu-Natal during this year.

\section{THEOLOGICAL REFLECTIONS}

We as co-researchers tried to examine the themes raised above in terms of theological ideas. We hoped that this would help us understand God's activity in the midst of police work. We explored how the above experiences have been shaped by our theological understanding as well as how theology can further challenge us in terms of doing police work in preferable ways. The theological ideas mentioned below correspond with the themes already highlighted.

\section{A God who calls us to excellence}

Part of the reason for declining standards and corruption is that many police personnel no longer see their work as a 'calling,' but merely as a job. The police officers that were interviewed expressed how God wanted them to do police work, even though other careers would have been more financially lucrative and that God's call upon their lives affected the quality of their work. This is the reason why they got frustrated when other police members only did the bare minimum.

One participant used the biblical text of the three servants receiving five, two and one talents respectively (Matt 25:1430). He saw this as God having given people different abilities and tasks, which we are called to use and develop to their fullest potential. In order to do this, attending regular courses (assuming that they are of good quality) and integrating them into daily practice is vitally important. He saw this as faithfully developing the talents God had given him.

Without a doubt, everything possible should be done to develop the skills of the members of the police. Training should be a regular occurrence, regardless of ranks and race. It should be of the highest quality, not only because the public demand good service, but because God calls us into attaining our fullest potential.

\section{A God who inspires us with a vision}

Moving our conversation from the context of both political and police leadership, we spoke about God who gives people a vision. Beyond the political point-scoring talk of politicians, there is a vision from God that is about establishing peace and justice in our country. While acknowledging that not all police members share that vision, it is the hope that God will ultimately bring about the fulfilment of this vision that helps officers to persevere. Glimpses of that realisation come through successes in apprehending and convicting criminals, when people work well together in responding to crime, etc. One participant summed it up by saying that even though we still have a long way to go, we will get there eventually.

Eschatology is the doctrine of last things. In it we find the hope that, ultimately, it is God's justice that will prevail over injustice, love over hate, compassion over apathy. It is the hope that history is going somewhere and that we are not on a meaningless expedition. Even in the times when we feel defeated by the overwhelming need and crime around us, we gain strength from the scriptural promise of what lies in the future and of which we have glimpses in our lives today.

\section{A God who grants us dignity}

At the heart of human rights is the conviction that we have all been made in the image of God (Gn 1:27-28). John Stott uses the three words dignity, equality and responsibility when writing on human rights, saying that we have the right to become fully human. This does not mean we can do as we please. The example he gives is that convicted criminals may be deprived of their right to freedom while imprisoned, but that does not justify treating the prisoner inhumanely (Stott 1984:144-146). He also points out the tragedy of human rights degenerating into 'my' rights irrespective of the rights of others. The biblical imperative is to champion the rights of the powerless and to love our neighbour (Stott 1984:146-148). Philippians chapter 2 is about Jesus who did not insist on his own rights despite being falsely accused and dying an unjust death. Through this he argues that we should entrust any injustice to a just Judge and focus our attention on taking a loving interest in others (Stott 1984).

Furthermore, Johannes van der Ven, Jaco Dreyer and Hendrik Pieterse state that Christianity's belief in salvation 'prompts people to claim and defend - even fight for - the human rights enshrined in the Bill of Rights' (Van der Ven, Dreyer \& Pieterse 2004:454). They go on to say that 'Christianity must help to invigorate an inspiring human rights culture, otherwise it will lose all relevance' (ibid. 2004:454). As difficult as this may be to implement in the context of violent crimes, it is a value in our constitution that is worth pursuing.

\section{A God of community}

The so-called new style of utilising the community in policing is more than a new political strategy of crime fighting. There is a theological basis to the community's (and church's) involvement in working with the police.

Scriptural examples of how God worked with people invite us into a full participation with God's work. Some examples in our conversations included the time Jesus used the five loaves and two fish brought by a little boy to miraculously feed the five thousand (Jn 6:1-14); the fact that Jesus called people into community life and discipleship, which is echoed by Paul's writings on the church being a community of respect and mutual edification; and the notion that intercessory prayer is based on us influencing God and being influenced by God. Indeed, God calls us into community life that involves edifying relationships. This applies to relationships amongst members of the police as well as relationships between the police and the communities they work within. Perhaps then we will see the miraculous (in terms of successful crime fighting) occur. An affirmation of these relationships leads this article into the specific role of the church. 


\section{A WAY FORWARD FOR THE CHURCH}

The role of the church in this community participation is both pastoral and prophetic.

On the pastoral side, practical issues such as involvement in crime prevention projects and community police forums; awareness campaigns (e.g. on domestic violence); and counselling and praying for police members at their work place are involved. At the very least it means acknowledging the complexities of policing under a new constitution and that simplistic assumptions about police officers' relationships with each other and their work are not always helpful or accurate. In my experience, bringing the gospel message of hope and encouragement in a humble and respectful way has always been met with appreciation from the police. This has been so even with those of other faiths and beliefs, especially when they see it as support from the local community. We are, after all, custodians of the theology described above. The church always needs to remind people (in this case the SAPS personnel) of diligence in work, of a vision of a better quality of life, of a God who grants dignity to everyone and so on. A message of Good News is about demonstrating our love through listening carefully to the stories of others and helping them to interpret those stories in the light of what God may be saying to them. It is a message that inspires people to something greater than their own prejudices and stories of despair. Helping people to realise this when we take their stories seriously, bringing them into dialogue with theology and the insights of others is one of the most fulfilling tasks we are called upon to fulfil as a church.

In the same way that community police forums were originally established for purposes of oversight and to prevent abuses of power by the police, the church also has a prophetic role to play. This may be a less popular role, but it is equally vital. While it was agreed that criticism could be destructive, the conclusion was drawn that it can be beneficial as well. This happens when the recipient realises that the one providing criticism is in favour of the recipient's growth. To use a personal example, when my supportive wife criticises my sermon, I know that she does so in my best interests and development rather than to break me down. Thus, speaking out against abusive practices, corruption, laziness, unfair promotional procedures and so on needs to become common practice. The church should not shy away from uncomfortable issues, especially when the criticism is provided in a spirit of upliftment towards increasing the quality of the work of individual police officers and the organisation as a whole. In the past the church has stood against many police practices in a spirit of opposition. As I developed a long-term relationship with members of the police, however, I discovered a method of confrontation that does not evoke antagonism. This was carried out through a joint critical reflection on the experiences these policemen faced. This may provide a clue towards how the institutions of church and police can build a relationship where a prophetic voice can be discerned together, thereby working towards peace and justice.

Thus, the church must be caring and understanding (as far as possible) as it listens to the stories that are shared. It must also continue speaking out against racism, corruption, human rights abuses, crime in all its forms (whether petty or priority crimes) and must cast a vision towards a safer and more just society. It must always uphold the values of integrity, excellence, good relationships and hope.

\section{CONCLUSION}

This research sought to identify a few issues experienced by members of the SAPS under a new constitution. The four areas focused on were the declining standards of work (and God's call to excellence); leadership and internal relationships (and God who inspires us with a bigger vision); human rights (and God who gives us dignity); and working with the broader community (based on a God of community). As the issues and challenges facing police officers were discussed, research participants were able to think about their lives and ideas. Some of them found their ideas entrenched, but were able to perceive exceptions to their problem-saturated stories. While not everyone had the theoretical knowledge of theology at their fingertips, the police participants gained insight into God's work in their daily lives. Helping people to come to this realisation is surely one of the main aims of the church in society. Regarding the further role of the church, it is important to add its possible contribution by helping police officials to deal constructively with the matters raised above in a way that is both pastoral and prophetic.

\section{NOTE}

Dr Brian Burger (PhD) is pastor of the Lyttelton Methodist Church in Centurion, South Africa. This article is based on his PhD degree in Practical Theology at the Faculty of Theology, University of Pretoria, entitled 'Exploring narratives of white male police officers serving in the South African Police Services in the Kwazulu-Natal Midlands area under a new constitution: A practical theological journey', completed under the supervision of Prof. Dr Julian Müller.

\section{REFERENCES}

Altbeker, A., 2005, The dirty work of democracy: A year on the streets with the SAPS, Jonathan Ball Publishers, Jeppestown.

Amnesty International, 2002, Policing to protect human rights: A survey of police practice in countries of the Southern African Development Community, 1997-2002, Amnesty International Publications, Oxford.

Burger, B., 2008, 'Exploring narratives of white male police officers serving in the South African Police Services in the Kwazulu-Natal Midlands area under a new constitution: A practical theological journey', PhD thesis, University of Pretoria.

Call to probe Indian cop saga, Sunday Tribune Herald, 15 October, 2006, p. 1.

Demasure, K. \& Müller, J., 2006, 'Perspectives in support of the narrative turn in pastoral care', Ned Geref Teologiese Tydskrif 47(3\&4), 410-419.

Freedman, J. \& Combs, G., 1996, Narrative Therapy: The social construction of preferred realities, Norton, New York.

Kotzé, E. \& Kotzé, D.J., 1997, 'Social construction as a post modern discourse: An epistemology for conversational therapeutic practice', Acta Theologica 17(1), 27-50.

MacDonald, G., 1989, Forging a real world faith, Highland Books, East Sussex.

Morgan, A., 2000, What is narrative therapy? An easy-to-read introduction, Dulwich Centre Publications, Adelaide.

Müller, J., 2004, 'HIV/AIDS, narrative practical theology, and postfoundationalism: The emergence of a new story', HTS Teologiese Studies/Theological Studies 60(1\&2), 293-306.

Müller, J., Van Deventer, W. \& Human, L., 2001, 'Fiction writing as metaphor for research: A narrative approach', Praktiese Teologie in Suid-Afrika 16(2), 76-96.

Steinberg, J. (ed.), 2001, Crime Wave: The South African underworld and its foes, Witwatersrand University Press, Johannesburg.

Stott, J., 1984, Issues facing Christians today, Marshalls, Hants.

Van der Merwe, C.N. \& Gobodo-Madikizela, P., 2008, Narrating our healing: Perspectives on working through trauma, Cambridge Scholars Publishing, Newcastle.

Van der Ven, J.A., Dreyer, J.S. \& Pieterse, H.J.C., 2004, Is there a God of human rights? The complex relationship between human rights and religion: $A$ South African Case, Brill, Leiden.

Van Huyssteen, J.W., 1999, The shaping of rationality: Toward interdisciplinarity in theology and science, William B. Eerdmans Publishing Co., Grand Rapids.

Van Rooyen, H.J.N., 1995, Community Policing, Promedial, Pretoria.

White, M. \& Epston, D., 1990, Narrative means to therapeutic ends, Norton, New York. 